at the expense perhaps of earnings from domiciliary visits or private work. In some areas universities appear willing to fund tutors in part.

Even given time and reward, however, is too much being asked of any one individual? How realistic is it to expect to find an interested and skilled teacher with the necessary administrative abilities in each hospital throughout the country? If unrealistic, at what level should the compromise be? Two tutors with complementary skills might share duties between them, or alternatively duties could be delegated, some perhaps to competent senior trainees. In a training scheme of any size the tutor may be more appropriately seen simply as a co-ordinator, being unable to cope alone with even a major part of the educational responsibilities. Other consultants would be expected to take their share of responsibility for specific areas-e.g. running the journal club, the library, the case conference, psychotherapy supervision, etc. Peripheral hospital tutors, often (but not always) isolated, might find local tutor group meetings helpful if they included members from the University Teaching Centre with the encouragement of the Postgraduate Dean. Here informa- tion and anxieties about individual trainees could be exchanged by different tutors who had taught him. This would be particularly helpful when faced with giving critical feedback to that person, a task often avoided because of uncertainty about one's individual judgement and fears about accusation of personal bias.

Trainees themselves must take an active responsibilitythey need to stimulate their tutors by showing an enthusiasm for progress. A well-organized peer group which meets regularly can become a major force for change. It is perhaps at this level that there is the most scope for creativity and it was on this optimistic note that $\mathrm{Dr}$ Thompson* drew the discussion to a close and thanked the speakers warmly for providing the basis for a highly successful Forum.

- The Collegiate Trainees' Committee has set up a working party to examine the problems of Psychiatric Tutors. If you have any comments about this report, or about any other aspects, whether you are tutor or trainee, please write to Dr C. Thompson, the Convener of the Working Party, at the Maudsley Hospital, Denmark Hill, London SE5.

\title{
Board of Examiners, 1984/85
}

Dr P. J. F. Aaronricks; Dr D. Abrahamson; Dr P. Aungle; Dr S. Benjamin; Dr G. Bennet; Dr I. Berg; Dr S. Bhanji; Professor D. J. Bicknell; Dr J. Bird; Dr A. D. Black; Dr S. Bloch; Professor R. Bluglass; Dr P. Bowden; Professor I. Brockington; Dr J. Brunning; Dr H.C. Cameron; Dr J. Candy; Dr P. A. Carney; Dr S. A. Checkley; Dr I. D. Chisholm; Dr J. Christie-Brown; Professor A. W. Clare; Dr J. Cobb; Dr J. Connolly; Dr A. F. Cooper; Dr J. L. Cox; Dr J. L. Crammer; Dr J. Cutting; Professor R. J. Daly; Dr R. Davidson; Dr D. M. Dickens; Dr J. H. Dowson; Dr R. J. Draper; Dr M. Duff-Miller; Dr G. Edwards; Dr H. G. Egdell; Dr A. El-Sobky; Professor T. Fahy; Dr W. Falkowski; Professor G. W. Fenton; Dr J. D. W. Fisher; Dr M. W. Forth; Dr O. S. Frank; Dr C. P. Freeman; Dr H. L. Freeman; Dr A. Fry; Dr R. Gardner; Dr A. M. Gath; Professor P. J. Graham; Professor J. Griffith Edwards; Dr J.S. Grimshaw; Professor J. Gunn; Dr P. Hall; Dr K. Hamadah; Dr B. G. Harwin; Dr M. T. Haslam; Dr G. G. Hay; Dr B. E. Heine; Dr L. Hemsi; Dr R. N. Herrington; Dr J. Higgins; Dr P. D. Hill; Professor S. R.
Hirsch; Dr B. D. Hore; Dr E. Howarth; Dr T. C. Jerram; Dr P. M. Jefferys; Dr J. Johnson; Dr E. C. Johnstone; Dr D. J. Jolley; Dr R. G. Jones; Dr J. Kellett; Dr P. F. Kennedy; Dr T. A. Kerr; Dr W. E. S. Kiernan; Dr R Kumar; Dr G. E. Langley; Professor W. A. Lishman; Dr G. Lloyd; Dr I. C. Lodge Patch; Dr W. A. G. MacCallum; Dr R. G. McCreadie; Dr F. McHarg; Dr A. V. P. Mackay; Dr E. K. McLean; Dr A. L. MacNeill; Dr S. Mann; Dr R. A. Mayou; Dr P. J. Meehan; Professor R. H. S. Mindham; Dr S. A. Montgomery; Professor H. G. Morgan; Dr J. K.W. Morrice; Dr R. M. Murray; Dr T. E. Nelson; Dr J.R. Pedder; Dr P. Pinkerton; Dr M. Pritchard; Dr P. H. Rack; Dr A. H. Reid; Dr B. Ritson; Dr A. Robin; Dr M. A. Ron; Professor R. M. Rosser; Dr P. H. Salmons; Dr G. Sedman; Dr D. M. Shaw; Dr A. C. Smith; Dr J. Sneddon; Dr G. F. Spaul; Dr J. Steinert; Dr E. Stonehill; Dr D. Storer; Dr P. Storey; Dr R. L. Symonds; Dr G. I. Szmukler; Dr L. Tarlo; Professor D. C. Taylor; Dr P. J. Taylor; Dr R. Thavasothy; Dr B. K. Toone; Professor A. Wakeling; Professor M. G. T. Webb; Dr P. Williams; Dr S. N. Wolkind; Dr A. K. Zealley.

\section{Book Club of the British Psycho-Analytical Society}

The Committee of the Book Club of the British PsychoAnalytical Society invites the members of the Royal College of Psychiatrists to join this Club. Membership offers the opportunity to purchase books in psycho-analysis and related subjects at substantial discounts on the usual retail prices. For details, please write to David Tuckett, Chairman, Book Club Committee, c/o The British Psycho-Analytical Society, 63 New Cavendish Street, London W1. 